\title{
REVIEW
}

\section{Strategies to reduce nutrient pollution from manure management in China}

\author{
David R. CHADWICK (凶) ${ }^{1,2}$, John R. WILLIAMS ${ }^{3}$, Yuelai LU ${ }^{4}$, Lin MA ${ }^{5}$, Zhaohai BAI ${ }^{5}$, Yong HOU ${ }^{6}$, \\ Xinping CHEN ${ }^{2}$, Thomas H. MISSELBROOK ${ }^{7}$ \\ 1 School of Natural Sciences, Bangor University, Bangor, LL57 2UW, UK \\ 2 Interdisciplinary Research Centre for Agriculture Green Development in Yangtze River Basin, Southwest University, \\ Chongqing 400715, China \\ 3 ADAS RSK, Boxworth, Cambridge, CB23 4NN, UK \\ 4 University of East Anglia, Norwich, NR4 7TJ, UK \\ 5 Key Laboratory of Agricultural Water Resources, Hebei Key Laboratory of Soil Ecology, Center for Agricultural Resources Research, \\ Institute of Genetic and Developmental Biology, Chinese Academy of Sciences, Shijiazhuang 050021, China \\ 6 College of Resources and Environmental Sciences, China Agricultural University, Beijing 100193, China \\ 7 Rothamsted Research, North Wyke, Devon, EX20 2LB, UK
}

\begin{abstract}
As the demand for livestock products continues to increase in China, so too does the challenge of managing increasing quantities of manure. Urgent action is needed to control point source (housing, storage and processing) and diffuse (field application) pollution and improve the utilization of manure nutrients and organic matter. Here, we review strategies to improve management at each stage of the manure management chain and at different scales. Many strategies require infrastructure investment, e.g., for containment of all manure fractions. Engineering solutions are needed to develop advanced composting systems with lower environmental footprints and design more efficient nutrient stripping technologies. At the field-scale, there is an urgent need to develop a manure nutrient recommendation system that accounts for the range of manure types, cropping systems, soils and climates throughout China. At the regional scale, coordinated planning is necessary to promote recoupling of livestock and cropping systems, and reduce nutrient accumulation in regions with little available landbank, while minimizing the risk of pollution swapping from one region to another. A range of stakeholders are needed to support the step change and innovation required to improve manure management, reduce reliance on inorganic fertilizers, and generate new business opportunities.
\end{abstract}

Keywords cropping farms, livestock production, manure management chain, recoupling, nutrient loss

Received July 25, 2019; accepted October 8, 2019

Correspondence: d.chadwick@bangor.ac.uk

\section{Introduction}

Livestock production continues to intensify in China to meet the increased demand for livestock products by a more affluent and growing human population and like many developed countries production is becoming more specialized $^{[1]}$. This specialization has become extreme in some regions of China, where the approach is to concentrate intensive landless livestock farms in periurban regions to provide fresh meat to the urban population. This requires importing feed from outside of the locality (even region and country), and results in concentration of manures and their nutrients, and some of their undesirable constituents (e.g., heavy metals, antibiotics, antibiotic resistant genes and odor), in areas with little or no available land. In contrast, traditional backyard and small livestock production systems still represent a significant contribution to the total livestock numbers in China. Both non-intensive (traditional animal feeding operations; TAFOs) and intensive systems (concentrated animal feeding operations; CAFOs) have significant shortcomings in terms of manure management that result in huge losses of nutrients to the environment with impacts on ecosystems ${ }^{[2,3]}$ and human health ${ }^{[4,5]}$. It is thought that livestock manures contribute around $30 \%$ of the $\mathrm{N}$ and $60 \%$ of the $\mathrm{P}$ found in the Yangtze River, and around $60 \%$ of the $\mathrm{N}$ and $60 \%$ of the $\mathrm{P}$ in the Yellow River in China ${ }^{[6]}$.

Fortunately, this situation has not gone unnoticed, and recent national policy has recognized that manure nutrient losses are a current acute problem that needs to be addressed. Effective manure nutrient management can 
offer part of the solution to reducing the overall inputs of nutrients to agricultural systems by reducing $\mathrm{N}$ surpluses and the subsequent environmental and human health impacts. For example, as part of the 2015 Zero Fertilizer Increase Input Policy ${ }^{[7]}$, there is a requirement to recycle at least $60 \%$ of manure to land and replace inorganic fertilizers with manure nutrients, with the recent Recycling of Livestock Manure Policy target for manure recycling being $75 \%$ by $2020^{[8]}$. This has led to the implementation of the 100 demonstration county project where local government supports innovative management practices to improve the sustainable recycling of manure nutrients, which has been recently extended to another 200 counties $^{[9]}$.

When considering improved manure nutrient management, it is essential to design strategies that complement each other through the manure management chain, i.e., the livestock housing, manure storage, manure processing and field application stages ${ }^{[10]}$ (Fig. 1), as the management practice at one stage may have indirect effects further along the chain and indeed, could lead to the complete loss of any benefit that had accrued at the earlier phase. This is particularly so for $\mathrm{NH}_{3}$ emissions and mitigation strategies to conserve $\mathrm{NH}_{3}-\mathrm{N}$ at any stage of the manure management chain ${ }^{[11]}$. Numerous recent international collaborative research programs with China have addressed various aspects of improved manure management, providing clear guidance and direction for the future research, policy and practice $^{[1,10-12]}$.
There are opportunities to reduce losses and improve nutrient use efficiency at all stages of the manure management chain, with some strategies being more applicable to certain scales of operation (Table 1). In the following sections we summarize these opportunities for housing, manure storage, processing and field application. We also summarize opportunities for improving manure nutrient use efficiency at local, regional and national scales, identifying the different stakeholder groups needed to support and contribute to the step change in innovation that is needed (Table 2).

\section{Housing and storage}

Nutrient losses from the housing plus storage stages (excluding direct discharge) are $49 \%$ (for $\mathrm{N}$ ) and $12 \%$ (for $\mathrm{P})$ of the total losses from the current manure management in China ${ }^{[13]}$ with both CAFOs and TAFOs representing significant sources of point pollution of water courses and emission to air ${ }^{[2,14]}$. The current level of direct discharge of the liquid fraction of excreta and manures is a matter of concern, e.g., Bai et al. ${ }^{[13]}$ estimate that $5.4 \mathrm{Tg} \cdot \mathrm{yr}^{-1} \mathrm{~N}$ (24\%) of excreted $\mathrm{N}$ and $1.9 \mathrm{Tg} \cdot \mathrm{yr}^{-1} \mathrm{P}(41 \%)$ of excreted $\mathrm{P}$ are directly discharged into watercourses from housing and storage facilities in China. It is estimated that direct discharge of manure accounted for $>65 \%$ of nutrients in the northern rivers and for $20 \%-95 \%$ of nutrients in central and southern rivers in $2000^{[2]}$. So, an immediate focus on

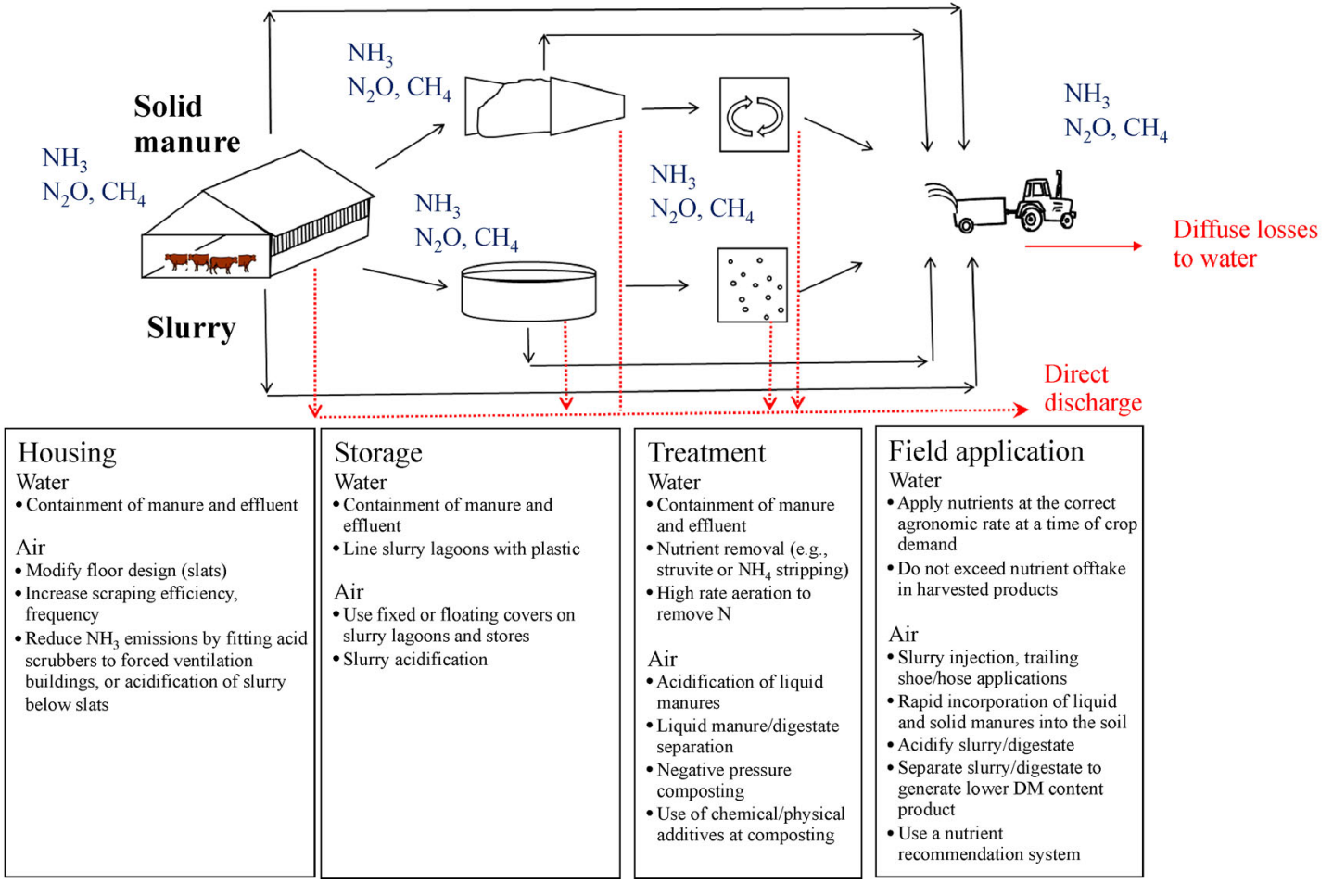

Fig. 1 Schematic representation of strategies to conserve nutrients and reduce losses to water and air at each stage of the manure management chain in China, adapted from Chadwick et al. ${ }^{[10]}$, with permission from Elsevier. 
Table 1 Management strategies for different scales of manure generation enterprises to improve nutrient retention at the different stages of the manure management chain and improve manure nutrient utilization

\begin{tabular}{|c|c|c|c|c|}
\hline Farm scale & Housing & Storage & Processing & Field application \\
\hline $\begin{array}{l}\text { Smallholder } \\
\text { (TAFO) }\end{array}$ & $\begin{array}{l}\text { - Containment } \\
\text { - Remove manure } \\
\text { frequently }\end{array}$ & $\begin{array}{l}\text { - Containment } \\
\text { - Cover manure store } \\
\text { - Sell manure to composting } \\
\text { factory }\end{array}$ & - Not practical & $\begin{array}{l}\text { - Small-scale machinery to transport manure } \\
\text { to own or neighbors' land } \\
\text { - Pay contractor to transport and spread } \\
\text { manure } \\
\text { - Use a manure recommendation system }\end{array}$ \\
\hline $\begin{array}{l}\text { Community } \\
\text { (TAFO) }\end{array}$ & $\begin{array}{l}\text { - Containment } \\
\text { - Remove manure } \\
\text { frequently }\end{array}$ & $\begin{array}{l}\text { - Containment } \\
\text { - Cover manure stores } \\
\text { - Manure acidification } \\
\text { - Sell manure to composting } \\
\text { factory or centralized } \\
\text { anaerobic digestion plant }\end{array}$ & $\begin{array}{l}\text { - Containment } \\
\text { - Separation } \\
\text { - Slurry aeration } \\
\text { - Composting solid fraction } \\
\text { - Liquid fraction for } \\
\text { fertigation } \\
\text { - Poultry litter for incineration }\end{array}$ & $\begin{array}{l}\text { - Small-scale machinery to transport } \\
\text { manure to own or neighbors' land } \\
\text { - Pay contractor to transport and spread } \\
\text { manure } \\
\text { - Use a manure recommendation system }\end{array}$ \\
\hline Large farm & $\begin{array}{l}\text { - Containment } \\
\text { - Remove manure } \\
\text { frequently } \\
\text { - Improve floor design } \\
\text { - Dry poultry litter } \\
\text { - Improve ventilation } \\
\text { design } \\
\text { - Use } \mathrm{NH}_{3} \text { scrubbers in } \\
\text { forced ventilated hous- } \\
\text { ing }\end{array}$ & $\begin{array}{l}\text { - Containment } \\
\text { - Cover manure stores } \\
\text { - Manure acidification } \\
\text { - Sell manure to composting } \\
\text { factory or centralized } \\
\text { anaerobic digestion }\end{array}$ & $\begin{array}{l}\text { - Containment } \\
\text { - Separation } \\
\text { - Slurry aeration } \\
\text { - Composting solid fraction } \\
\text { - Liquid fraction for } \\
\text { fertigation } \\
\text { - Anaerobic digestion } \\
\text { - Poultry litter incineration }\end{array}$ & $\begin{array}{l}\text { - Use own machinery to transport } \\
\text { manure to own or neighbors' land } \\
\text { - Pay contractor to transport and spread } \\
\text { manure } \\
\text { - Contracts with local farmers to receive } \\
\text { manures } \\
\text { - Use a manure recommendation system }\end{array}$ \\
\hline $\begin{array}{l}\text { Intensive farm } \\
\text { (CAFO) }\end{array}$ & $\begin{array}{l}\text { - Containment } \\
\text { - Remove manure } \\
\text { frequently } \\
\text { - Improve floor design } \\
\text { - Dry poultry litter } \\
\text { - Improve ventilation } \\
\text { design } \\
\text { - Use } \mathrm{NH}_{3} \text { scrubbers in } \\
\text { forced ventilated hous- } \\
\text { ing }\end{array}$ & $\begin{array}{l}\text { - Containment } \\
\text { - Cover manure stores } \\
\text { - Manure acidification } \\
\text { - Sell manure to composting } \\
\text { factory or centralized } \\
\text { anaerobic digestion }\end{array}$ & $\begin{array}{l}\text { - Containment } \\
\text { - Separation } \\
\text { - Composting solid fraction } \\
\text { - Liquid fraction for } \\
\text { - fertigation } \\
\text { - Anaerobic digestion }\end{array}$ & $\begin{array}{l}\text { - Use own machinery to transport } \\
\text { manure to own or neighboring farmers' land } \\
\text { - Pay contractor to transport and spread } \\
\text { manure } \\
\text { - Contracts with local farmers to receive } \\
\text { manures } \\
\text { - Transfer production to new region with } \\
\text { available landbank } \\
\text { - Sell own compost or liquid fraction with } \\
\text { adequate labeling } \\
\text { - Use a manure recommendation system }\end{array}$ \\
\hline $\begin{array}{l}\text { Composting } \\
\text { factory }\end{array}$ & & & $\begin{array}{l}\text { - Containment } \\
\text { - Optimize aeration style, } \\
\text { rate } \\
\text { - Use additives to reduce } \\
\mathrm{NH}_{3} \text { and GHG emissions }\end{array}$ & $\begin{array}{l}\text { - Sell own compost or liquid fraction with } \\
\text { adequate labeling } \\
\text { - Use own machinery to transport } \\
\text { compost to own or neighboring } \\
\text { farmers' land }\end{array}$ \\
\hline $\begin{array}{l}\text { Centralized AD } \\
\text { plant }\end{array}$ & & & $\begin{array}{l}\text { - Containment } \\
\text { - Cover digestate and } \\
\text { feedstock stores }\end{array}$ & $\begin{array}{l}\text { - Sell digestate with adequate labeling } \\
\text { - Use own machinery to transport } \\
\text { digestate to own or neighboring } \\
\text { farmers' land }\end{array}$ \\
\hline
\end{tabular}

Table 2 Recommendations for the staged improvement of manure management in China indicating the groups affected and the stakeholders needed to generate the enabling environment and innovation to achieve the significant step change required

\begin{tabular}{|c|c|c|c|}
\hline Stages of management & $\begin{array}{l}\text { Recommendations to improve manure } \\
\text { management }\end{array}$ & Group affected & Enabling stakeholder groups \\
\hline \multirow[t]{2}{*}{$\begin{array}{l}\text { Stop point source } \\
\text { pollution }\end{array}$} & $\begin{array}{l}\text { Contain all manure effluent, i.e., prevent } \\
\text { direct discharge of manure to watercourses }\end{array}$ & $\begin{array}{l}\text { Community livestock farms } \\
\text { TAFOs } \\
\text { CAFOs } \\
\text { Composting factories } \\
\text { Anaerobic digestion plants }\end{array}$ & $\begin{array}{l}\text { Financiers, via loans or subsidies: } \\
\text { provincial government, central } \\
\text { government and engineering } \\
\text { industry }\end{array}$ \\
\hline & $\begin{array}{l}\text { Reduce gaseous losses (ammonia and } \\
\text { greenhouse gases) from point sources, e.g., } \\
\text { fit acid scrubbers, biofilters to forced- } \\
\text { ventilation animal buildings and } \\
\text { composting factories. Cover slurry stores. }\end{array}$ & $\begin{array}{l}\text { CAFOs } \\
\text { Composting factories } \\
\text { Anaerobic digestion plants }\end{array}$ & $\begin{array}{l}\text { Financiers, via loans or subsidies: } \\
\text { provincial government, central } \\
\text { government and engineering } \\
\text { industry }\end{array}$ \\
\hline
\end{tabular}




\begin{tabular}{ll}
\hline Stages of management & $\begin{array}{l}\text { Recommendations to improve manu } \\
\text { management }\end{array}$ \\
\hline $\begin{array}{l}\text { Stop excessive nutrient } \\
\text { applications }\end{array}$ & $\begin{array}{l}\text { Do not apply more nutrients than can } \\
\text { be removed in the crop }\end{array}$ \\
& $\begin{array}{l}\text { Generate an ongoing database of } \\
\text { nutrient content of typical manures } \\
\text { and separated fractions }\end{array}$
\end{tabular}

Label manure products with individual macro-nutrient contents

Generate a market for all fractions of separated manures, e.g., fertigation of high $\mathrm{N}$ availability (low $\mathrm{P}$ ) liquid fraction

Restore nutrient balancesfield scale

Restore nutrient balancesat larger geographical scale
Develop an integrated manure and fertilizer recommendation system

Improve infrastructure for transporting manure to fields

Improve infrastructure for spreading manure to crops

Village-county scale:

Promote transfer of manure from enterprises that generate manure to farmers that can utilize the manure, i.e., promote recoupling of livestock and cropping system

Province-national scale:

Develop a coordinated approach to nutrient planning through siting new livestock production enterprises in regions with adequate landbank

- Link with policies to improve water and air quality

- Ensure adequate infrastructure to limit point source pollution in new zones of production

Group affected Enabling stakeholder groups

Fruit farmers Extension officers

Greenhouse vegetable farmers $\quad$ STB programs

Cropping famers

Paddy rice farmers

Community livestock farms

CAFOs

Composting factories

Anaerobic digestion plants

CAFOs

Composting factories

Anaerobic digestion plants

TAFOs

Community livestock farms

CAFOs

Composting factories

Anaerobic digestion plants

Fruit farmers

Greenhouse vegetable farmers

Cropping famers

Paddy rice farmers

Fruit farmers

Greenhouse vegetable farmers

Cropping famers

Paddy rice farmers

Fruit farmers

Greenhouse vegetable farmers

Cropping famers

Paddy rice farmers

Community livestock farms

CAFOs

Composting factories

Anaerobic digestion plants

Cropping farmers

Fruit farmers

Greenhouse vegetable farmers

Paddy rice farmers

CAFOs

Composting factories

Anaerobic digestion plants

Cropping farmers

Fruit farmers

Greenhouse vegetable farmers Paddy rice farmers
Nutrient utilization researchers Commercial laboratories

Provincial government

Central government

Commercial laboratories

Agriculture Bureau

Agriculture Engineering researchers Industry (business opportunities)

Agriculture Bureau

Nutrient utilization researchers Agriculture Extension Service STB programs

Financiers, via loans or subsidies: provincial government,

central government, financial institutions, and engineering industry

Small-scale contractors

CAFOs

Composting factories

Anaerobic digestion plants

Financiers, via loans or subsidies: provincial government, central government and engineering industry Small-scale contractors

CAFOs

Composting factories

Anaerobic digestion plants

Local planning authorities

Provincial government

Financiers, via loans or subsidies

Engineering Industry

Small-scale contractors

Agriculture Bureau

STB programs

Nutrient utilization researchers

Regional planners

Provincial government

National government

Financers, via loans or subsidies

Nutrient utilization researchers 
reducing discharges to as close to zero is essential and will require all manure and effluent to be contained. This will be more easily achieved and verified in the larger landless production systems than the millions of backyard and small farms. However, this should not be seen as a barrier to implementation. It may require innovative engineering solutions, in terms of designing cheap and easy-to-use containment systems, and subsidies may be required to expedite the adoption within a short time frame. Complete containment will have indirect consequences, i.e., more manure nutrients will be retained ${ }^{[13]}$ that will then need safe transfer through the rest of the manure management chain for later field application and recycling for crop growth.

In addition, reducing the high $\mathrm{NH}_{3}$ losses from housing systems is likely to require changes to floor designs, although many current systems already separate liquid from solid excreta deposited on housing floors in northern China ${ }^{[10]}$. More frequent scraping and flushing of concrete floors will reduce emissions of $\mathrm{NH}_{3}{ }^{[15,16]}$, but care must be taken to continue to conserve the saved $\mathrm{N}$ during the storage, processing and field application phases. On large mechanically ventilated installations, air scrubbers provide a potential option for reducing $\mathrm{NH}_{3}$ and particulate matter (PM) emissions, with the possibility of recapturing the $\mathrm{NH}_{3}$ as a fertilizer solution product. Evaporation and increasing the size of liquid manure stores will lead to increases in $\mathrm{NH}_{3}$ emission and contribute to $\mathrm{PM}$ formation at the local level.

The Blue Sky Act (2018) in China has set targets to reduce concentration of both $\mathrm{SO}_{2}$ and $\mathrm{NO}_{x}$ by $15 \%$ between 2015 and 2020, respectively, with the emphasis of increasing manure recycling ${ }^{[17]}$, but without a target for reducing $\mathrm{NH}_{3}$ emissions. This is less comprehensive than the current legislation in the $\mathrm{EU}^{[18]}$, which requires member states to reduce emissions of $\mathrm{SO}_{2}, \mathrm{NO}_{x}$, nonmethane volatile organic compounds and $\mathrm{NH}_{3}$ to agreed targets, and the requirements for UK farmers to reduce $\mathrm{NH}_{3}$ emissions from manure stores and field application, as specified in the UK's recent Clean Air Strategy ${ }^{[19]}$. Guidance documents and Framework Codes of Good Agricultural Practice have been developed to help achieve these targets ${ }^{[20-22]}$. A clear strategy for reducing $\mathrm{NH}_{3}$ emissions from China's agricultural systems is urgently needed ${ }^{[23]}$.

\section{Processing}

China has adopted a range of technologies for processing livestock manures, including liquid-solid separation, composting, anaerobic digestion and biological nitrification-denitrification treatment. The majority of manure that is collected on CAFOs is composted (especially for poultry), with a much smaller proportion used for anaerobic digestion (mainly pigs and dairy cows) $)^{[24,25]}$.
In TAFOs, however, the majority of manure that is collected and spread to land is not treated. Separation offers an opportunity to remove the liquid fraction and compost the solid fraction that can then be transported to regions where there is adequate land for application.

Composting technology is developing rapidly in China. While there are different composting techniques, including groove type fermentation, windrow composting and invessel composting to treat solid manure, windrow composting is the most common technology used, but results in large losses of $\mathrm{NH}_{3}$ and $\mathrm{N}_{2} \mathrm{O}^{[26,27]}$. A range of mitigation strategies have been proposed to reduce these losses, including the use of biological, chemical and physical additives ${ }^{[27]}$, as well as a controlled aeration rate $^{[28]}$. Forced aeration, coupled with acidification has been shown to be effective in reducing ammonia emissions as well as total greenhouse gas emissions (expressed as $\left.\mathrm{kg} \cdot \mathrm{t}^{-1} \mathrm{CO}_{2} \mathrm{e}\right)^{[29]}$.

Windrow composting requires large areas of concrete for efficient operation and there has been recent interest in the development and use of in-vessel composting with a smaller area footprint. Additional benefits of in-vessel composting include a more rapid throughput of feedstocks, more control of the aeration rate and mixing rate, the ability to alter the direction of the air flow and the potential to include technical solutions to recapture $\mathrm{N}$ from $\mathrm{NH}_{3}$ emission. For example, Wang et al. ${ }^{[30]}$ used negative pressure aeration to compost pig manure resulting in lower $\mathrm{NH}_{3}$ emission compared to positive aeration treatments. The negative pressure aeration also reduced total global warming potential, when direct $\mathrm{N}_{2} \mathrm{O}$ and $\mathrm{CH}_{4}$ emissions, as well as indirect $\mathrm{N}_{2} \mathrm{O}$ emissions associated with $\mathrm{NH}_{3}$ losses, were taken into account from the composting process. Further efforts are needed to reduce the $\mathrm{NH}_{3}$ and GHG emissions from composting/digestion factories.

To reduce direct discharge of liquid manures into watercourses, some farms have constructed large lagoons and rely on evaporation to concentrate the manure, with subsequent $\mathrm{NH}_{3}$ emissions and nitrate leaching. The challenge that will have to be met as more manures are contained, will be management of the nutrients in the liquid fraction of separated manures. Recent advances have included nutrient stripping, e.g., via the formation of struvite $^{[31]}$, and there are engineering opportunities to scale up nutrient recovery (e.g., $\mathrm{NH}_{4}^{+}, \mathrm{P}$ ) from the liquid fraction for reuse as fertilizer products. The use of screw press separators generates a liquid fraction with a low solid content that can be used in fertigation, and there is evidence that this practice is being used in some regions of China at a commercial scale. However, for both high value composts and liquid fractions, adequate labeling is needed of the individual nutrients to enable farmers to determine how much product should be used to deliver the required $\mathrm{N}, \mathrm{P}$ or $\mathrm{K}$ to meet crop demand. Often, current labeling provides only the total combined NPK content.

Slurry acidification is being explored at the research 
scale to assess its potential to reduce $\mathrm{NH}_{3}$ emission during storage $^{[32]}$ and processing, and after field application ${ }^{[33]}$. The co-benefits of slurry acidification can be reductions in methane emissions during slurry storage ${ }^{[34]}$, possibly because of inhibited methanogenesis in acidic conditions. Slurry acidification is largely implemented and promoted in Denmark, but rarely in other regions. Further efforts are needed to assess at which stage of the manure management chain it is most cost-effective to acidify manure, and what additional benefits there are in combining treatment technologies, e.g., mechanical separation and acidification $^{[35]}$ to reduce $\mathrm{NH}_{3}$ emissions and improve nitrogen use efficiency. It is also important to consider the choice, availability and safety of using concentrated acidification products, as well as providing adequate training and advice to ensure effective adoption of this treatment technology by farmers and spreading contractors. Current lack of availability of specialist equipment for the acidification of the solid fraction of manures reduces the scale of adoption of acidification ${ }^{[35]}$. In addition, the application of concentrated acids to livestock slurries in China would need to comply with the standards for liquid organic fertilizers, in terms of e.g., NPK and heavy metal contents.

Anaerobic digestion (AD) offers the opportunity to generate electricity and heat that can be used on farm or sold back to the grid. AD can also be used to co-digest livestock slurry with other organic wastes, before the digestate is returned to the land. Digested slurry can contain a higher proportion of the total $\mathrm{N}_{\text {as }} \mathrm{NH}_{4}{ }^{+}$than in raw slurry, but this may not necessarily result in an increase in crop-available $\mathrm{N}$ supply because this increase in the $\mathrm{NH}_{4}{ }^{+}-\mathrm{N}$ is relatively small, and because of the higher risk of $\mathrm{NH}_{3}$ volatilization from digestate when spread onto land ${ }^{[36]}$. Digestate stores need an effective cover to reduce emissions of $\mathrm{NH}_{3}$, or the digestate could be acidified to reduce losses from the store.

Nitrification and denitrification treatment ${ }^{[37]}$ may be an option to reduce $\mathrm{N}$ surplus in regions with high livestock density and limited arable land, and also where there are logistical difficulties to transport surplus manure to other regions. The resulting sludge requires storage before application, and the liquid effluent needs to meet the discharge standard before it can be disposed to waterbodies. However, previous research has shown that $\mathrm{N}_{2} \mathrm{O}$ losses from such systems can be high ${ }^{[38]}$. The promotion of nitrification and denitrification treatment for livestock manure can be marginal due to the high investment for installation and the operation cost associated with the energy required for (1) oxygen transfer to achieve nitrification, and (2) separation of raw manure ${ }^{[39]}$. Finally, incineration of poultry litter offers a potential opportunity to generate electricity euhere poultry manure nutrients cannot be used effectively, e.g., in regions of concentrated poultry production units with little land-base, and the transport distances to centralized incineration-electricity generating plants make this economically feasible ${ }^{[40]}$.

\section{Field application}

A coordinated research effort is needed to develop a manure nutrient recommendation system for China, that provides guidance on the availability of $\mathrm{N}, \mathrm{P}$ and $\mathrm{K}$ from different livestock categories and production systems applied to the range of soil types and cropping systems. Such a system would need to include fertigation of vegetables and fruit using the separated liquid fraction of manures. The MANNER-NPK decision support system in the UK is a good example of this approach ${ }^{[41]}$.

Key steps toward developing a manure nutrient recommendation system include: (1) the development of a continually updated database of manure nutrient composition (dry matter content, $\mathrm{pH}$, total $\mathrm{N}$, total $\mathrm{P}$, total $\mathrm{K}$ and total $\mathrm{NH}_{4}{ }^{+}-\mathrm{N}$, and $\mathrm{NO}_{3}{ }^{-} \mathrm{N}$ for solid manures); (2) the quantification of mineralization rates of different manure types in different soil and climatic conditions as not all of the manure $\mathrm{N}$ will be plant available ${ }^{[42]}$; (3) the collation of data (and new data collection where appropriate) on $\mathrm{NH}_{3}$, denitrification and $\mathrm{NO}_{3}^{-}$leaching losses following application of different manure types to the range of soils and climates in China; (4) the collation of data and new data collection for manure fertilizer $\mathrm{N}$ replacement rates to validate the decision support system; and (5) the training in integrated nutrient management for farmers and extension workers. However, as a first step to reduce nutrient surpluses and subsequent diffuse pollutant losses, farmers should be incentivized to limit nutrient inputs to balance the nutrient offtake in harvested products (Table 2). The nutrient balance, i.e., nutrient surplus or deficit $\left(\mathrm{kg} \cdot \mathrm{ha}^{-1}\right)$, is a useful indicator of sustainable production $^{[43]}$. In some countries, e.g., England there is a requirement for farmers to have an annual nutrient management plan based on soil analysis, crop nutrient requirement and an assessment of manure crop available nutrient supply to guide manufactured fertiliser inputs ${ }^{[44]}$. This nutrient management planning has been introduced in the UK via the 'Farming Rules for Water', to reduce excessive nutrient applications and subsequent risk of pollution to water courses, while maintaining adequate nutrient supply for optimum crop yields and quality ${ }^{[44]}$.

Since $\mathrm{NH}_{3}$ emissions represent a significant agronomic loss of $\mathrm{N}$ following manure spreading, a range of mitigation strategies should be explored, including the use of shallow injection, trailing hose/shoe ${ }^{[45]}$ and rapid incorporation. In addition, slurry acidification is known to reduce $\mathrm{NH}_{3}$ emissions from liquid slurries and digestate $^{[33,36]}$, so further information on the costs, practicalities and attitudes to this technology is needed for production systems in China. Although much of this $\mathrm{NH}_{3}$ mitigation technology has been developed for large equipment in the EU, there is opportunity for smaller-scale spreading equipment to be developed that would be more suitable for the smaller land areas in China. To enable smallholders 
to gain the benefits of farm mechanization, the Chinese government is promoting the development of the farm machine service organizations and providers ${ }^{[46]}$. According to MARA ${ }^{[46]}$, by the end of 2012, China's agricultural machine service organizations reached 167 thousand, and the service providers reached 5.2 million. Indeed, as part of the agricultural green development strategy, the Chinese government has adjusted the agricultural subsidies categories, with machines and facilities for livestock manure recycling (including collection, storage and land application) being eligible for priority subsidies ${ }^{[47]}$.

Key factors influencing the mismanagement of manure applications in China include the lack of available labor to transport manure from the place of generation to the field and for subsequent field applications ${ }^{[10]}$. There is also a reluctance to use slurry or the liquid fraction of separated manure on crops or vegetables because of perceived issues with heavy metal and pathogen contamination. However, suitable treatment such as composting ${ }^{[48]}$ and anaerobic digestion ${ }^{[49,50]}$ can significantly reduce pathogen loads in manures prior to field application. Moreover, to further reduce bacterial pathogens to a significant level, in-vessel composting may be a preferred technology, as it also reduces antibiotics and antibiotic resistance genes, as well as ammonia and greenhouse gases ${ }^{[29]}$.

Off-farm work has contributed to suboptimal use of nutrient inputs and crop agronomy in China. However, this provides an opportunity for new businesses to transport manure to the field and to spread manure to crops. These businesses could also act as nutrient management services, applying manure to crops at the required rate. The small land areas of many smallholder farms mean that mechanization is limited, but there are engineering opportunities to design small liquid and solid manure application equipment. So, with formal and informal land consolidation and transfer increasing, and cropping farmers in the same village growing the same crop and using small-scale contractors to harvest, e.g., maize and other crops ${ }^{[51]}$, there is great opportunity for mechanization to improve resource use efficiencies in these situations. China is speeding up agricultural mechanization and upgrading farming machines and facilities ${ }^{[52]}$. Development and dissemination of green mechanization, including manure recycling machines and facilities, as well as machines suitable for small-scale operations are among the priorities.

\section{Whole system approaches}

Although there is a range of promising strategies to retain nutrients at each stage of the manure management chain (see Fig. 1 and above), there are some strategies that could have an impact at all stages of the chain. Slurry acidification is one strategy that could be implemented in the animal house, with the potential to continue to reduce emissions from the manure store, during processing and following field application-although research would be needed to test the effectiveness of this, and determine if additional acidification might be needed at other stages of the manure management chain.

Bai et al. ${ }^{[13]}$ present an in-depth assessment of nutrient flows in the manure management chain in China, using simulation modeling (NUFER). Total $\mathrm{N}, \mathrm{P}$ and $\mathrm{K}$ excretions by livestock were $22.8,4.6$ and $16.2 \mathrm{Tg}$ in 2010 , respectively. About $21 \%$ of the manure $\mathrm{N}$, and $50-53 \%$ of manure $\mathrm{P}$ and $\mathrm{K}$ were recycled. The losses of nutrient (including field losses) were high in the manure chain, with 17.8 $\mathrm{Tg} \mathrm{N}, 2.6 \mathrm{Tg} \mathrm{P}$ and $8.2 \mathrm{Tg} \mathrm{K}$ lost to environment in 2010. Greatest losses occurred from animal housing and manure storage. Mixed livestock production systems and other cattle were the largest contributors to $\mathrm{N}$ losses. The business as usual scenario indicated that total losses in 2020 will have increased further by $15 \%$ for N, $12 \%$ for $\mathrm{P}$ and $22 \%$ for $\mathrm{K}$, due to increases in animal food consumption. Significant reductions of nutrient losses $(27 \%-56 \%)$ and input of fertilizer $(27 \%-100 \%)$ can be achieved by the combination of prohibiting manure discharge, improving manure collection and preservation in storage, and improving manure application methods. To achieve such a target, current policies, subsidies and research studies on manure management should shift from the focus solely on composting or digestion to the whole manure management chain approach in China ${ }^{[53]}$.

Dietary manipulation strategies, i.e., reducing the crude protein content of livestock diets and supplementation of specific amino acids to the diet, have the potential to significantly reduce $\mathrm{N}$ excretion. Reduction in manure $\mathrm{N}$ content has the potential to reduce $\mathrm{NH}_{3}$ emissions and other $\mathrm{N}$ losses through the entire manure management chain $^{[34]}$. Lower levels of crude protein were also shown to reduce manure $\mathrm{pH}$, further reducing the risk of $\mathrm{NH}_{3}$ loss. The discharge of $\mathrm{P}$ from livestock husbandry to water bodies has contributed largely to eutrophication of water bodies in China ${ }^{[54]}$. Supplementing diets with phytase or supplements containing high concentrations of watersoluble $\mathrm{P}$ can reduce total $\mathrm{P}$ excretion. Supplementing diets with phytase or animal-derived feed ingredients can increase $\mathrm{P}$ digestibility and reduce total $\mathrm{P}$ excretion ${ }^{[55,56]}$. Research has indicated that diets supplemented with microbial phytase $\left(1000 \mathrm{U} \cdot \mathrm{kg}^{-1}\right)$ increased $\mathrm{P}$ retention in growing pigs by $30 \%$ and decreased fecal $\mathrm{P}$ by $45 \%{ }^{[56]}$.

\section{Regional and national scale strategies}

Approaches to improve manure nutrient management at the field and farm scale have been described above. However, coordinated planning at the regional and national scale could reduce the pressure on land (Table 1). Planning for new CAFOs should be based on the availability of land (the available landbank) to safely use the manure nutrients generated $^{[57]}$, or manures (or fertilizer products resulting 
from manure processing) may need to be exported to other regions to balance the large import of nutrients in animal feed $^{[58-60]}$. Alternatively, local planning should enforce contracts between large, intensive landless livestock producers and local farmers to ensure manure nutrients are recycled to land.

There is opportunity for either livestock producers or small-scale contractors to provide nutrient transport and spreading services, providing integrated nutrient management planning to support optimal crop growth. This recoupling of livestock with cropping farms is a goal shared by the Agricultural Green Development Program in China ${ }^{[61]}$ and has a number of important co-benefits. These include (1) adding organic matter to cropping soils, (2) substitution of chemical fertilizers, (3) reduction in environmental impacts of poor manure management practices, and (4) improving the sustainability of crop production and quality of food products. Recently, national policy has closed pig production enterprises in southern China and is encouraging new pig production facilities in northern provinces ${ }^{[60]}$. The aim of this national redistribution of pig production is to safeguard vulnerable watercourses in the southern provinces and to site new livestock production systems in regions with sufficient landbank for the effective use of the manure generated. However, this national scale recoupling needs to be carefully coordinated and requires the new livestock production systems to contain all manure, have adequate manure storage facilities and have contracts with neighboring cropping farmers to ensure manures are appropriately recycled back to land. This will ensure that nutrient loadings and pollution is not simply being swapped from one region to another ${ }^{[60]}$.

Although China already has some key Water Protection Zones, e.g., around Lake Taihu, where livestock production is forbidden, $\mathrm{NO}_{3}{ }^{-}$accumulation is of concern in many areas of China ${ }^{[62]}$. Consequently, designation of nutrient vulnerable zones, similar to the Nitrate Vulnerable Zones designated in the EU, could be used to enforce specific measures for the management of livestock manures ${ }^{[1]}$. These manure management measures could include (1) closed periods when manure spreading is not permitted, e. g., if excess rainfall causes nutrient leaching, (2) minimum manure storage capacity, to ensure farms can store manure for sufficient time to ensure applications are only made at the time of crop demand, and (3) maximum annual nutrient loadings to soil, to minimize nutrient accumulation in soils.

\section{Enabling environment}

It is clear that there are tremendous opportunities for China to improve manure management at all scales, viz. field, farm (including TAFO, CAFO, composting factory and anaerobic digestion plants), village, province and national (Table 1; Table 2), which will result in significant economic, environmental and human health benefits. However, efforts need to be coordinated and effective solutions cannot be delivered by just one actor, e.g., researchers. Research is key to improving manure management, e.g., in developing innovative technologies to reduce $\mathrm{NH}_{3}$ losses during composting, providing data to underpin the develop a manure nutrient recommendation system. Research is also vital to improve understanding how to promote adoption of new technologies and management practices, and address the socioeconomic factors influencing farmer decision making. However, many of the strategies identified in Table 1 and Table 2 require additional stakeholder engagement to develop an enabling environment for the innovation and step change required.

Policy support via reallocated subsidies, banks and industry are needed to reduce the financial constraints for improved manure management practices, e.g., purchasing manure containment facilities, establishing new smallscale contractor businesses for transporting and spreading manures, and the development of small-scale manure spreading equipment. Recoupling of livestock enterprises and composting factories and anaerobic digestion plants with local farmers will require local planning authorities to recommend sites for new livestock enterprises based on the need of local cropping farmers for manure nutrients. In addition, manure exchange contracts will need to be set up, reviewed and enforced between the manure provider and manure receivers. While there should be a social obligation of large manure generators (CAFOs, composting factories and anaerobic digestion plants) to ensure that their manures are used properly, there is a tremendous opportunity for these enterprises to increase their commercial activities and act as the manure transport and spreading service in their locality. The Agricultural Bureau may need to have a role in promoting this scale of recoupling between livestock enterprises and cropping farms at the county-provincial scale. At a larger spatial scale, recoupling of livestock enterprises with cropping, fruit, vegetable and rice farmers will need coordinated planning to determine the optimal regions for siting new livestock enterprises, e.g., based on the available landbank for receiving manure nutrients, and taking into account Water Protection Zones, None Livestock Production Zones, Ecological Redline Zones, and ensuring newly sited livestock enterprises and associated composting factories are equipped with adequate infrastructure to ensure that environmental burdens are not just moved from one region to another ${ }^{[60]}$.

Training and communication of improved technologies and management practices will be necessary. The Agricultural Extension Service coupled with the Science and Technology Backyard (STB) program will be key to delivering guidance and facilitating adoption of best management practices within livestock farms as well as on farms that use the manure nutrients. Mobile phone information service systems, such as the number 112316 
from MARA and Nongxintong, offer opportunities to communicate regular guidance on improved manure management practices with different farming groups, increasing the reach of the current STB program, and this could be coupled with future innovation in, for example, micro tasks for micro-payments ${ }^{[63]}$, to receive feedback from farmers on persistent constraints to adoption.

\section{Conclusions}

There is no single solution to improving manure management across the range of livestock and cropping farming systems in China, and different approaches and technologies will be more applicable in different regions and to different scales, requiring a good understanding of the constraints and opportunities available in each case. However, there are a number of recommendations common to most stakeholders (Table 1): (1) reduce point source pollution, e.g., by containment of all manure, (2) restore nutrient balances at field and regional levels by not applying more nutrient than is removed in the crop, (3) develop and implement a manure nutrient recommendation system for the range of manure types, soils, climates and cropping systems in China, (4) coordinate planning to encourage recoupling of livestock and cropping farmers at the local, regional and national scale, (5) provide effective communication of new guidance that encourages adoption, and (6) provide strong governance and policing of new rules and regulations. An increased social responsibility by producers (e.g., CAFOs and composting plants) and users of manure nutrients is needed. A coordinated approach by a range of stakeholder groups and enabling institutions, including research institutions, provincial and central government, agriculture bureaus, industry, financing institutions, agriculture extension services will be needed to generate and maintain the enabling environment to support the step change and innovation to improve manure management at each stage of the manure management continuum, and at multiple scales.

Although manures currently represent a well documented threat to both human and environmental health, they can and will be part of the solution to the oversupply of nutrients to soil and soil degradation in China. They offer great opportunity to help China meet its Zero Increase Inputs Policy target, by increasing the replacement of fertilizer nutrients with manure nutrients and provide the essential link between the livestock and cropping farms, returning valuable organic matter to degraded soils. In addition, the strategies that are necessary to improve manure nutrient management will create new job and business opportunities, e.g. in developing and delivering engineering solutions, and via small-scale service providers for transporting and spreading manures.
Acknowledgements The authors acknowledge support from the Academy for Agricultural Green Development, the UK-China Virtual Joint Centres on Nitrogen, N-Circle and CINAg, funded by the Newton Fund via UK BBSRC/ NERC (BB/N013484/1 and BB/N013468/1, respectively), and the Chinese Ministry of Science and Technology, and the Sustainable Agriculture Innovation Network (SAIN). We also acknowledge financial support from the National Natural Science Foundation of China (31772393) for supporting Yong Hou.

Author Contributions Statement DRC instigated this paper, drafting the structure and intended content. All authors contributed equally to the writing of this paper.

Compliance with ethics guidelines David R. Chadwick, John R. Williams, Yuelai Lu, Lin Ma, Zhaohai Bai, Yong Hou, Xinping Chen, and Thomas H. Misselbrook declare that they have no conflicts of interest or financial conflicts to disclose.

This article does not contain any studies with human or animal subjects performed by any of the authors.

\section{References}

1. Bai Z, Lu J, Zhao H, Velthof G L, Oenema O, Chadwick D, Williams J R, Jin S, Liu H, Wang M, Strokal M, Kroeze C, Hu C, Ma L. Designing vulnerable zones of nitrogen and phosphorus transfers to control water pollution in China. Environmental Science \& Technology, 2018, 52(16): 8987-8988

2. Strokal M, Ma L, Bai Z, Luan S, Kroeze C, Oenema O, Velthof G, Zhang F. Alarming nutrient pollution of Chinese rivers as a result of agricultural transitions. Environmental Research Letters, 2016, 11 (2): 024014

3. Yu C, Huang X, Chen H, Godfray H C J, Wright J S, Hall J W, Gong P, Ni S, Qiao S, Huang G, Xiao Y, Zhang J, Feng Z, Ju X, Ciais P, Stenseth N C, Hessen D O, Sun Z, Yu L, Cai W, Fu H, Huang X, Zhang C, Liu H, Taylor J. Managing nitrogen to restore water quality in China. Nature, 2019, 567(7749): 516-520

4. Kang Y, Liu M, Song Y, Huang X, Yao H, Cai X, Zhang H, Kang L, Liu X, Yan X, He H, Zhang Q, Shao M, Zhu T. High-resolution ammonia emissions inventories in China from 1980 to 2012. Atmospheric Chemistry and Physics, 2016, 16(4): 2043-2058

5. Liu M, Huang X, Song Y, Tang J, Cao J, Zhang X, Zhang Q, Wang S, Xu T, Kang L, Cai X, Zhang H, Yang F, Wang H, Yu J Z, Lau A K H, He L, Huang X, Duan L, Ding A, Xue L, Gao J, Liu B, Zhu T. Ammonia emission control in China would mitigate haze pollution and nitrogen deposition, but worsen acid rain. Proceedings of the National Academy of Sciences of the United States of America, 2019, 116(16): 7760-7765

6. Strokal M, Kroeze C, Wang M, Bai Z, Ma L. The MARINA model (Model to Assess River Inputs of Nutrients to seAs): model description and results for China. Science of the Total Environment, 2016, 562: 869-888

7. Ministry of Agriculture and Rural Affairs (MARA). Zero growth in synthetic fertilizer use from 2020 onwards, 2015. Available at MARA of the People's Republic of China website on October 25, 2019 (in Chinese)

8. Ministry of Agriculture and Rural Affairs (MARA). Recycling of livestock manure' policy the target for manure recycling is $75 \%$ by the end of 2020, 2017. Available at MARA of the People's Republic 
of China website on October 25, 2019 (in Chinese)

9. Ministry of Agriculture and Rural Affairs (MARA). Guidelines for implementation of livestock manure recycling projects in 2019, 2019. Available at MARA of the People's Republic of China website on October 25, 2019 (in Chinese)

10. Chadwick D, Jia W, Tong Y, Yu G, Shen Q, Chen Q. Improving manure nutrient management towards sustainable agricultural intensification in China. Agriculture, Ecosystems \& Environment, 2015, 209: 34-46

11. Bai Z, Li X, Lu J, Wang X, Velthof G L, Chadwick D, Luo J, Ledgard S, Wu Z, Jin S, Oenema O, Ma L, Hu C. Livestock housing and manure storage need to be improved in China. Environmental Science \& Technology, 2017, 51(15): 8212-8214

12. Wang M, Ma L, Strokal M, Chu Y, Kroeze C. Exploring nutrient management options to increase nitrogen and phosphorus use efficiencies in food production of China. Agricultural Systems, 2018, 163: 58-72

13. Bai Z, Ma L, Jin S, Ma W, Velthof G L, Oenema O, Liu L, Chadwick D, Zhang F. Nitrogen, phosphorus, and potassium flows through the manure management chain in China. Environmental Science \& Technology, 2016, 50(24): 13409-13418

14. Zhang L, Chen Y, Zhao Y, Henze D K, Zhu L, Song Y, Paulot F, Liu X, Pan Y, Lin Y, Huang B. Agricultural ammonia emissions in China: reconciling bottom-up and top-down estimates. Atmospheric Chemistry and Physics, 2018, 18(1): 339-355

15. Monteny G J, Erisman J W. Ammonia emission from dairy cow buildings: a review of measurement techniques, influencing factors and possibilities for reduction. Netherlands Journal of Agricultural Science, 1998, 46(3): 225-247

16. Burchill W, Reville F, Misselbrook T H, O'Connell C, Lanigan G J. Ammonia emissions and mitigation from a concrete yard used by cattle. Biosystems Engineering, 2019, 184: 181-189

17. The State Council of the People's Republic of China. The Blue Sky Act, 2018. A notice on the three-year action plan to win the battle to protect the Blue Sky, 2018. Available at the State Council of The People's Republic of China website on July 3, 2018 (in Chinese)

18. EU Directive. EU 2016/2284 of the European Parliament and of the Council of 14 December 2016 on the reduction of national emissions of certain atmospheric pollutants, amending Directive 2003/35/EC and repealing Directive 2001/81/EC. Official Journal of the European Union, 2016, L 344 17.12.2016: 1-31

19. Defra. Clean Air Strategy 2019. Available at UK Government website on October 25, 2019

20. Bittman S, Dedina M, Howard C M, Oenema O, Sutton M A. Options for ammonia mitigation: guidance from the UNECE Task Force on Reactive Nitrogen, NERC/Centre for Ecology \& Hydrology. Edinburgh, UK, 2014

21. Defra. Department for Environment, Food \& Rural Affairs. Code of Good Agricultural Practice (COGAP) for Reducing Ammonia Emissions 2018. Available at UK Government website on October 25, 2019

22. UNECE. Framework Code for Good Agricultural Practice for Reducing Ammonia Emissions. Published by the European Commission, Directorate-General Environment on behalf of the Task Force on Reactive Nitrogen of the UNECE Convention on
Long-range Transboundary Air Pollution, 2015. Available at UNECE website on October 25, 2019

23. Bai Z, Winiwarter W, Klimont Z, Velthof G, Misselbrook T, Zhao Z, Jin X, Oenema O, Hu C, Ma L. Further improvement of air quality in China needs clear ammonia mitigation target. Environmental Science \& Technology, 2019, 53(18): 10542-10544

24. Wang F, Dou Z, Ma L, Ma W, Sims J T, Zhang F. Nitrogen mass flow in China's animal production system and environmental implications. Journal of Environmental Quality, 2010, 39(5): 15371544

25. Meng X, Xu Z, Wu G, Ou W, Li J, He W. Analysis of utilization of fecal resources in large-scale livestock and poultry breeding in China. Journal of Agricultural Resources and Environment, 2018, 35(2): 126-132

26. Martins O, Dewes T. Loss of nitrogenous compounds during composting of animal wastes. Bioresource Technology, 1992, 42(2): 103-111

27. Cao Y, Wang X, Bai Z, Chadwick D, Misselbrook T, Sommer S, Qin W, Ma L. Mitigation of ammonia, nitrous oxide and methane emissions during solid waste composting with different additives: a meta-analysis. Journal of Cleaner Production, 2019, 235: 626-635

28. Yuan J, Chadwick D, Zhang D, Li G, Chen S, Luo W, Du L, He S, Peng S. Effects of aeration rate on maturity and gaseous emissions during sewage sludge composting. Waste Management, 2016, 56: 403-410

29. Tong B, Wang X, Wang S, Ma L, Ma W. Transformation of nitrogen and carbon during composting of manure litter with different methods. Bioresource Technology, 2019, 293: 122046

30. Wang X, Bai Z, Yao Y, Gao B, Chadwick D, Chen Q, Hu C, Ma L. Composting with negative pressure aeration for the mitigation of ammonia emissions and global warming potential. Journal of Cleaner Production, 2018, 195: 448-457

31. Taddeo R, Honkanen M, Kolppo K, Lepistö R. Nutrient management via struvite precipitation and recovery from various agroindustrial wastewaters: process feasibility and struvite quality. Journal of Environmental Management, 2018, 212: 433-439

32. Finzi A, Riva E, Bicoku A, Guido V, Shallari S, Provolo G. Comparison of techniques for ammonia emission mitigation during storage of livestock manure and assessment of their effect in the management chain. Journal of Agricultural Engineering, 2019, 50 (1): $12-19$

33. Sánchez-Rodríguez A R, Carswell A M, Shaw R, Hunt J, Saunders K, Cotton, Chadwick D, Jones D L, Misselbrook T H. Advanced processing of food waste based digestate for mitigating nitrogen losses in a winter wheat crop. Frontiers in Sustainable Food Systems, 2018, 2: 35

34. Hou Y, Velthof G L, Oenema O. Mitigation of ammonia, nitrous oxide and methane emissions from manure management chains: a meta-analysis and integrated assessment. Global Change Biology, 2015, 21(3): 1293-1312

35. Fangueiro D, Hjorth M, Gioelli F. Acidification of animal slurry-a review. Journal of Environmental Management, 2015, 149: 46-56

36. Nicholson F, Bhogal A, Cardenas L, Chadwick D, Misselbrook T, Rollett A, Taylor M, Thorman R, Williams J. Nitrogen losses to the environment following food-based digestate and compost applications to agricultural land. Environmental Pollution, 2017, 228: 504- 
516

37. Vanotti M B, Ro K S, Szogi A A, Loughrin J H, Millner P. High-rate solid-liquid separation coupled with nitrogen and phosphorus treatment of swine manure: effect on water quality. Frontiers in Sustainable Food Systems, 2018, 2: 49

38. Béline F, Martinez J, Chadwick D, Guiziou F, Coste C M. Factors affecting nitrogen transformations and related nitrous oxide emissions from aerobically treated piggery slurry. Journal of Agricultural Engineering Research, 1999, 73(3): 235-243

39. Bernet N, Béline F. Challenges and innovations on biological treatment of livestock effluents. Bioresource Technology, 2009, 100 (22): 5431-5436

40. Billen P, Costa J, Van der Aa L, Van Caneghem J, Vandecasteele C. Electricity from poultry manure: a cleaner alternative to direct land application. Journal of Cleaner Production, 2015, 96: 467-475

41. Nicholson F A, Bhogal A, Chadwick D, Gill E, Gooday R D, Lord E, Misselbrook T, Rollett A J, Sagoo E, Smith K A, Thorman R E, Williams J R, Chambers B J. An enhanced software tool to support better use of manure nutrients: MANNER-NPK. Soil Use and Management, 2013, 29(4): 473-484

42. Bhogal A, Williams J R, Nicholson F A, Chadwick D, Chambers K $\mathrm{H}$, Chambers B J. Mineralization of organic nitrogen from farm manure applications. Soil Use and Management, 2016, 32(S1): 3243

43. Organization for Economic Co-operation and Development (OECD). Nutrient balance (indicator). Available at OECD website on October 25, 2019

44. Department for Environment, Food \& Rural Affairs (DERRA). Farming rules for water-getting full value from fertilisers and soil, 2018. Available at UK Government website on October 25, 2019

45. Misselbrook T H, Smith K A, Johnson R A, Pain B F. Slurry application techniques to reduce ammonia emissions: results of some UK field-scale experiments. Biosystems Engineering, 2002, 82(3): 313-321

46. Ministry of Agriculture and Rural Affairs (MARA). Guidelines on advancing agricultural machine services, 2013. Available at MARA of the People's Republic of China website on October 25, 2019 (in Chinese)

47. Ministry of Agriculture and Rural Affairs (MARA). Priorities for financial support to agriculture in 2018, 2018. Available at MARA of the People's Republic of China website on October 25, 2019 (in Chinese)

48. Pandey P K, Vaddella V, Cao W, Biswas S, Chiu C, Hunter S. Invessel composting system for converting food and green wastes into pathogen free soil amendment for sustainable agriculture. Journal of Cleaner Production, 2016, 139: 407-415

49. Alfa M I, Adie D B, Igboro S B, Oranusi U S, Dahunsi S O, Akali D M. Assessment of biofertilizer quality and health implications of anaerobic digestion effluent of cow dung and chicken droppings. Renewable Energy, 2014, 63: 681-686

50. Manyi-Loh C E, Mamphweli S N, Meyer E L, Okoh A I, Makaka G, Simon M. Inactivation of selected bacterial pathogens in dairy cattle manure by mesophilic anaerobic digestion (balloon type digester). International Journal of Environmental Research and Public
Health, 2014, 11(7): 7184-7194

51. Yi Q, Chen M, Sheng Y, Huang J. Mechanization services, farm productivity and institutional innovation in China. China Agricultural Economic Review, 2019, 11(3): 536-554

52. The State Council of the People's Republic of China. Guidelines for speeding up agricultural mechanization and upgrading of agricultural machanization and upgrading of agricultural machines and facilities, 2018. Available at the State Council of the People's Republic of China website on December 29, 2018 (in Chinese)

53. Wang Y, Dong H, Zhu Z, Gerber P J, Xin H, Smith P, Opio C, Steinfeld H, Chadwick D. Mitigating greenhouse gas and ammonia emissions from swine manure management: a system analysis. Environmental Science \& Technology, 2017, 51(8): 4503-4511

54. Ministry of Ecology and Environment (MEE) of the People's Republic of China. The first national pollution census bulletin, 2010. Available at MEE of the People's Republic of China website on October 25, 2019 (in Chinese)

55. Emiola A, Akinremi O, Slominski B, Nyachoti C M. Nutrient utilization and manure $\mathrm{P}$ excretion in growing pigs fed corn-barleysoybean based diets supplemented with microbial phytase. Animal Science Journal, 2009, 80(1): 19-26

56. Kim B G, Lee J W, Stein H H. Energy concentration and phosphorus digestibility in whey powder, whey permeate, and low-ash whey permeate fed to weanling pigs. Journal of Animal Science, 2012, 90 (1): 289-295

57. Nicholson F A, Humphries S, Anthony S G, Smith S R, Chadwick D, Chambers B J. A software tool for estimating the capacity of agricultural land in England and Wales for recycling organic materials (ALOWANCE). Soil Use and Management, 2012, 28(3): 307-317

58. Jia W, Yan Z, Chadwick D, Kang L, Duan Z, Bai Z, Chen Q. Integrating soil testing phosphorus into environmentally based manure management in peri-urban regions: a case study in the Beijing area. Agriculture, Ecosystems \& Environment, 2015, 209: $47-59$

59. Wei S, Bai Z H, Chadwick D, Hou Y, Qin W, Zhao Z Q, Jiang R F, Ma L. Greenhouse gas and ammonia emissions and mitigation options from livestock production in peri-urban agriculture: Beijing - a case study. Journal of Cleaner Production, 2018, 178: 515-525

60. Bai Z, Jin S, Wu Y, Ermgassen E, Oenema O, Chadwick D, Lassaletta L, Velthof G, Zhao J, Ma L. China's pig relocation in balance. Nature Sustainability, 2019, 2(10): 888

61. Ministry of Agriculture and Rural Affairs (MARA). Implementation of Five Actions towards Agricultural Green Development, 2017. Available at MARA of the People's Republic of China website on October 25, 2019 (in Chinese)

62. Lu J, Bai Z, Velthof G L, Wu Z, Chadwick D, Ma L. Accumulation and leaching of nitrate in soils in wheat-maize production in China. Agricultural Water Management, 2019, 212: 407-415

63. Bell A R, Ward P S, Killilea M E, Tamal M E H. Real-time social data collection in rural bangladesh via a 'Microtasks for Micropayments' Platform on Android smartphones. PLoS One, 2016, 11(11): e0165924 